\title{
KIMBERLITE PIPES: GROWTH MODELS AND RESULTING IMPLICATIONS FOR DIAMOND EXPLORATION \\ Volker Lorenz ${ }^{1}$ and Stephan Kurszlaukis ${ }^{2}$ \\ ${ }^{1}$ Institut fuer Geologie, Würzburg, Germany; ${ }^{2}$ De Beers GeoScience Centre, South Africa
}

\section{PIPE GROWTH MODELS AND ROOT ZONE PROCESSES}

A kimberlite dyke represents the feeder through which magma is fed into an actively evolving kimberlite pipe. In the phreatomagmatic model of pipe formation, it is usually the top end of the feeder dyke where the dyke magma interacts in many individual thermohydraulic explosions with groundwater.

If the groundwater is contained in hard rocks in a (sub)vertical fault or pronounced joint zone then these highly energetic explosions initially occur close to the earth's surface. A sequence of explosions leads to the formation of a number of explosion chambers which

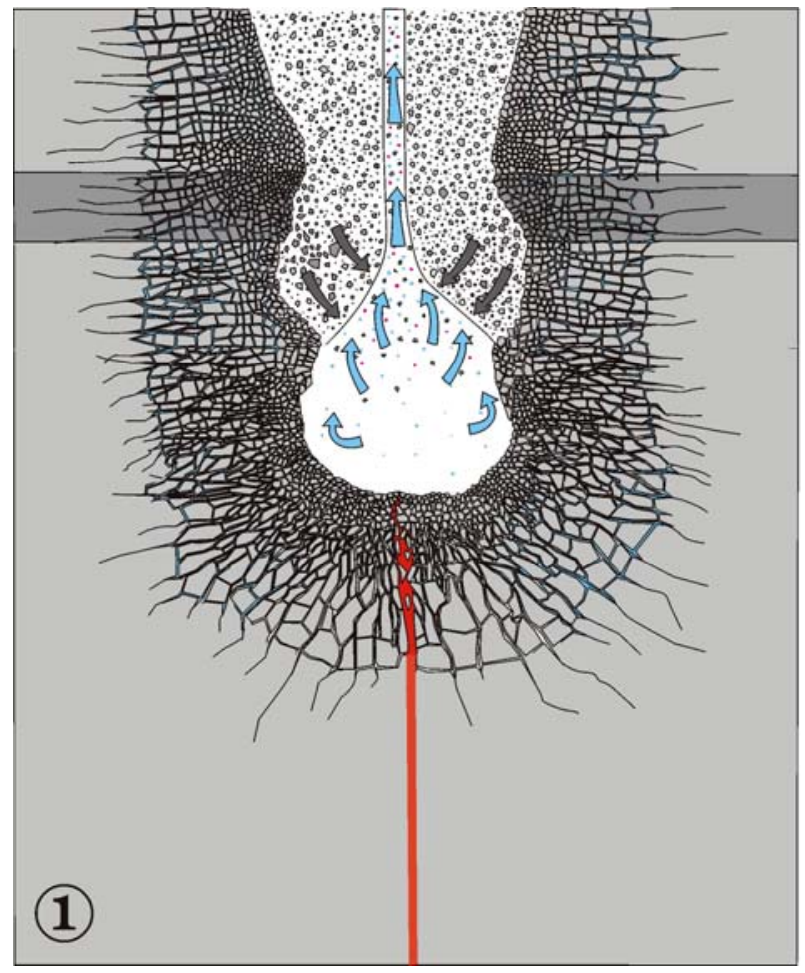

jointly form the initial irregular-shaped root zone. Ejection of fragmented kimberlite magma and country rock clasts and the resulting rock mechanical instability of the roof and walls of the root zone cause collapse of the overlying and surrounding country rocks into the partly evacuated root zone (Figs. 1 to 4 ). The growing collapse zone above the downward penetrating root zone is a rather regular cone-shaped subsidence structure, a diatreme, which acts like a sink hole filled by subsiding country rocks and primary and reworked tephra originating from the collapse of arcuate slices of the outward growing maar tephra ring. The maar crater overlying the diatreme forms initially by direct blast of shallow seated thermohydraulic explosions and subsequently via collapse of the underlying root zone, i.e. through subsidence.

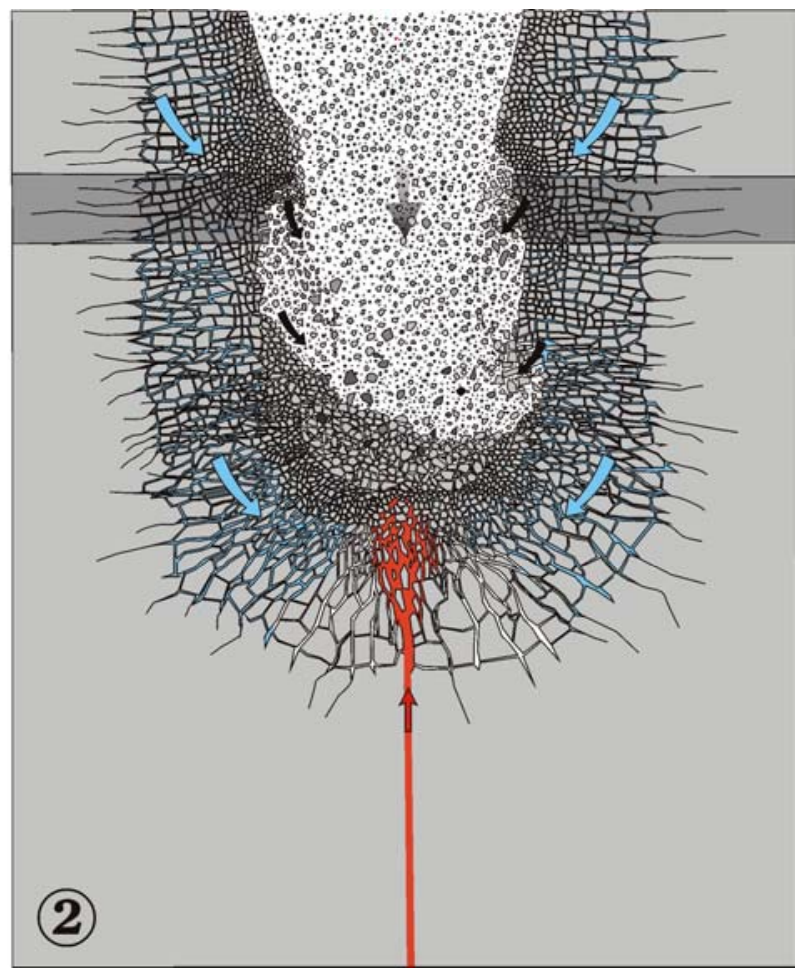

Figure 1: The figure shows the root zone and the lowest part of the diatreme directly after the previous explosion and eruption (the overlying part of the diatreme and the crater is omitted from the drawing; see also Fig. 5). The country rock is highly brecciated and the explosion chamber is temporarily evacuated by the eruption through the feeder vent. Consequently a shortlived cavity forms at the site of the explosion. The dark grey band represents a hypothetical layer (bed) of a harder rock.

Figure 2: The newly formed explosion chamber is filled by rockfalls and rockslides from the unstable brecciated side walls of the cavity and also by material subsiding from higher explosion chamber(s) and the overlying diatreme. Magma intrudes into the contact breccia (and possibly also into the rockfall breccia) and water is seeping and shooting in from the brecciated side walls, the overlying diatreme, and the aquifer or hydraulically active zone of structural weakness on which the volcano is forming. 

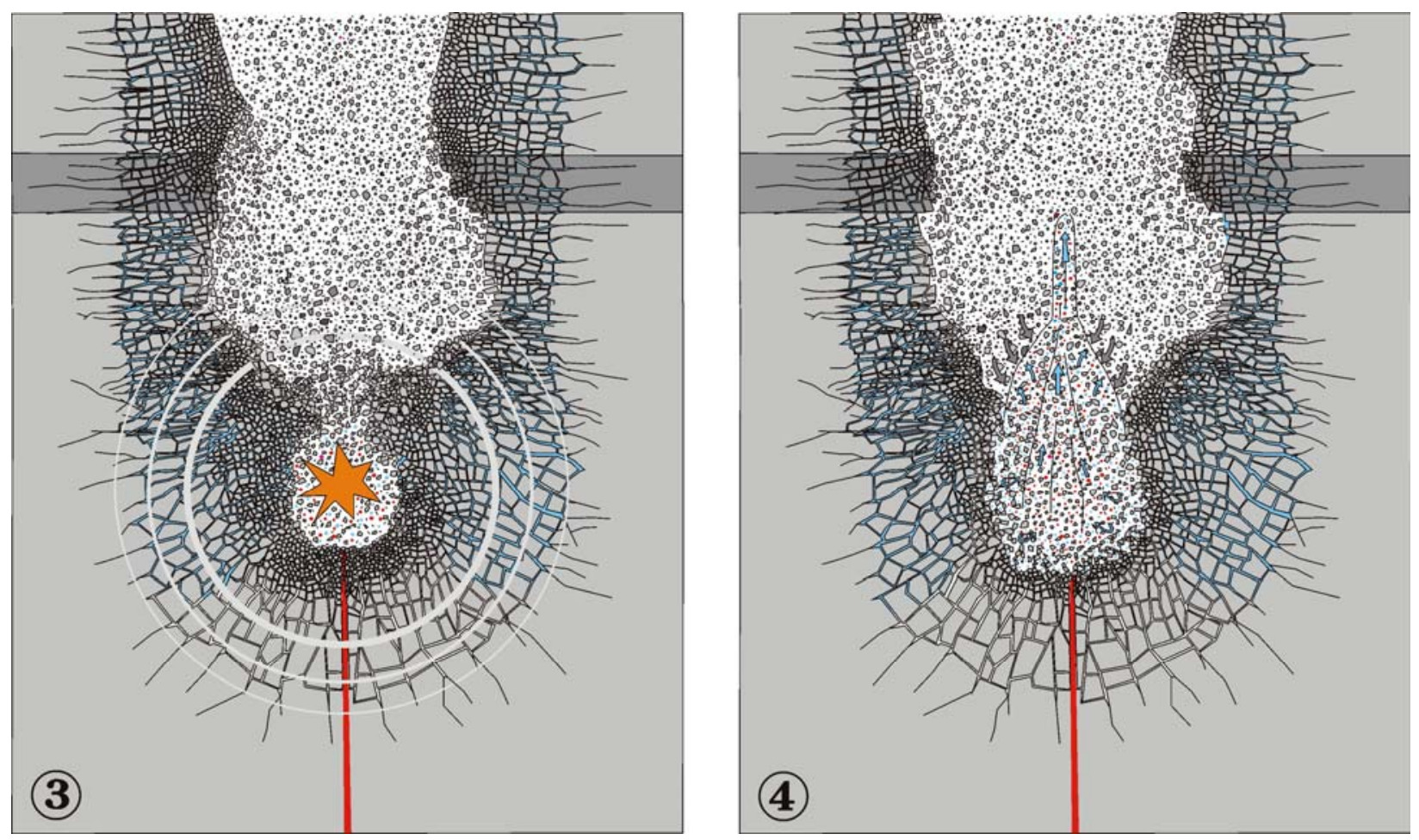

Figure 3: Situation immediately after a new explosion and with beginning eruption: highly energetic shock waves are emitted by the explosion and brecciate the country rock next and beneath the site of the previous explosion (Figure 1). The beginning volume expansion due to the generation of steam pushes the material overlying the explosion centre upwards (plug flow).

Figure 4: Eruption Phase. The expanding vapor creates a magma-solid-water-vapor system that expands against the over-lying diatreme-filling tephra, through which it will finally pierce in form of a feeder vent, ejecting the material into the atmosphere above the maar crater floor. The explosion chamber will be evacuated and a short-lived cavity is developed (Figure 1). During the cyclic phases of explosion, eruption, collapse, intrusion and renewed explosion at deeper levels, the root zone and the diatreme penetrates downward and simultaneously the diatreme grows radially outward through upward migrating side wall collapse.

If the groundwater is contained in a (sub)horizontal water-rich and relatively thin aquifer and if this aquifer is located close to the earth's surface, then a wide maar crater will be formed that flares from the aquifer. If the aquifer is not further cut by (sub)vertical hydrologically active faults then the root zone, which in this special case equals the maar crater, will not penetrate downward and only a maar crater without an underlying diatreme is developed. Most of the Fort à la Corne kimberlites in Canada (Scott Smith et al., 1998) and the Mbuji Mayi pipes in the DRC (De Maiffe et al., 1986) may be examples for such aquifer-controlled maars.

\section{...AND THE RESULTING IMPLICA- TIONS FOR DIAMOND EXPLORATION}

\section{1: PRIMARY DEPOSITS}

In terms of exploration for primary diamond deposits it is essential to understand the following relationship:
The growth of a kimberlite pipe depends on the optimal reflux and mixing ratio of ascending magma and groundwater over time. If this mixing ratio is maintained to its optimum and long enough, very large and deep diatremes can be formed (e.g. South Africa (Lorenz, 1973, 1985) or Russia (Mahotkin et al., this volume)). However, if the magma/water reflux rate is not maintained to its optimum, than only small diatremes or scoria cones which may be underlain by initial diatremes develop. The water/magma reflux rate can vary considerably even within the same volcanic field. This means that within the same volcanic field large diatremes can be formed in close vicinity to small diatremes of the same age, depending on the magma/water reflux rate (Fig. 5). For the Venetia kimberlite cluster, South Africa, Kurszlaukis and Barnett (2003) describe the presence of large pipes filled with bedded volcaniclastic material next to small pipes which show features of the lower diatreme or even the root zone at the same erosional level.

If the groundwater is provided predominantly in hydrologically active faults, then magma away from 


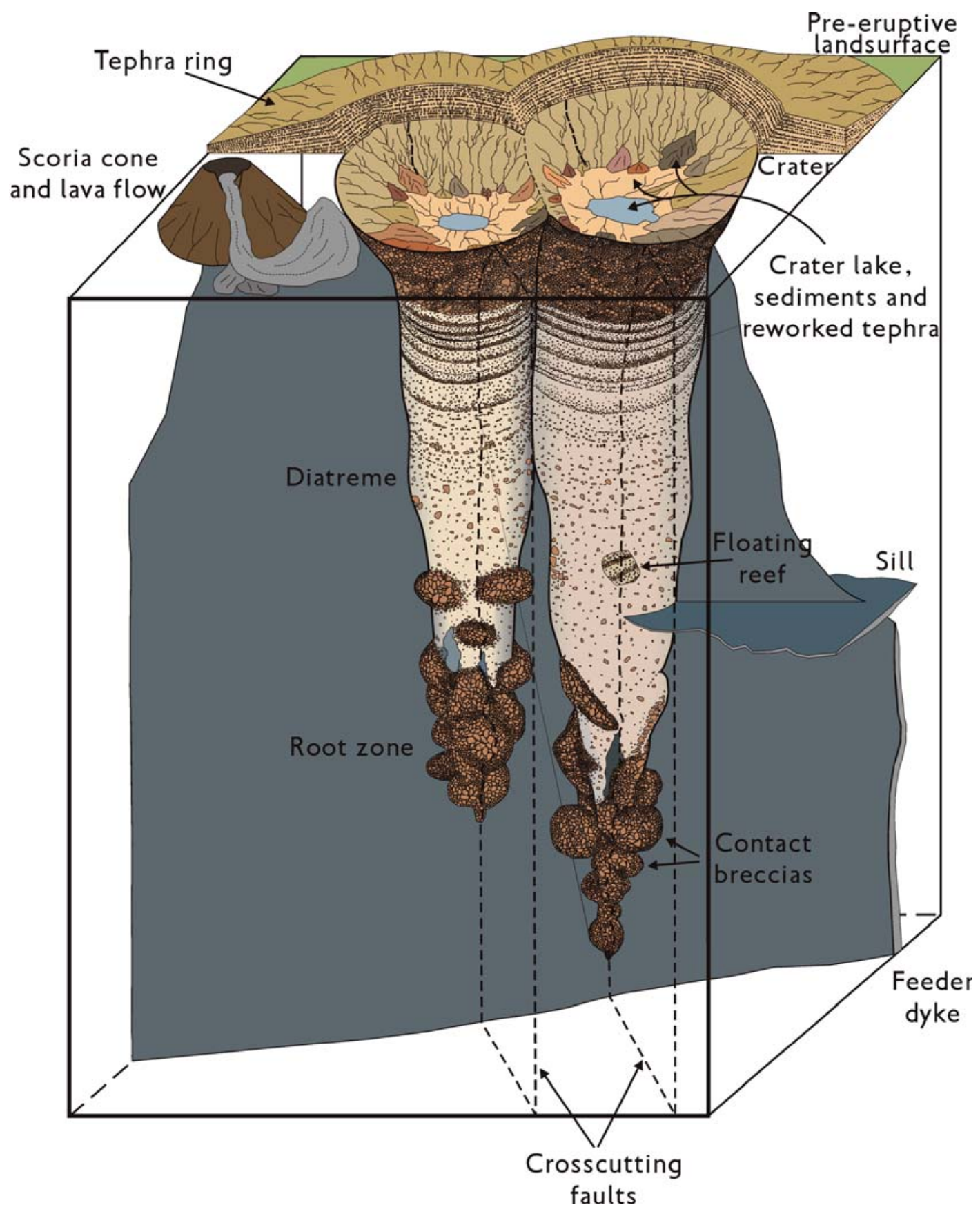

Figure 5: The figure shows a schematic $3 \mathrm{~d}$ block diagram of possible kimberlite volcanic landforms occurring in the same area and formed at the same time. Note that the root zones may have different depths, depending on the magma/water reflux rate.

these can locally reach the earth's surface without any groundwater interaction. There it can form scoria cones as well as lava flows (Fig. 5). Igwisi Hills in Tanzania is such an uneroded rare example (Dawson, 1994).

Diatreme growth ends if either the magma ascent or the water reflux into the root zone ceases. If the magma supply stops and only water still enters the root zone then the root zone will be filled predominantly by collapse breccias of the surrounding country rocks (Fig.
6). Only minor kimberlite ore will be present in this scenario and the root zone will most probably be not economical for exploitation. Alternatively, if the water supply stops and magma is still intruding the root zone without interacting explosively, then massive hypabyssal kimberlite intrusions may develop, which, depending on the diamond grade, may represent economical deposits (Fig. 7). Deeply eroded pipes like The Oaks mine in South Africa (Lorenz and 

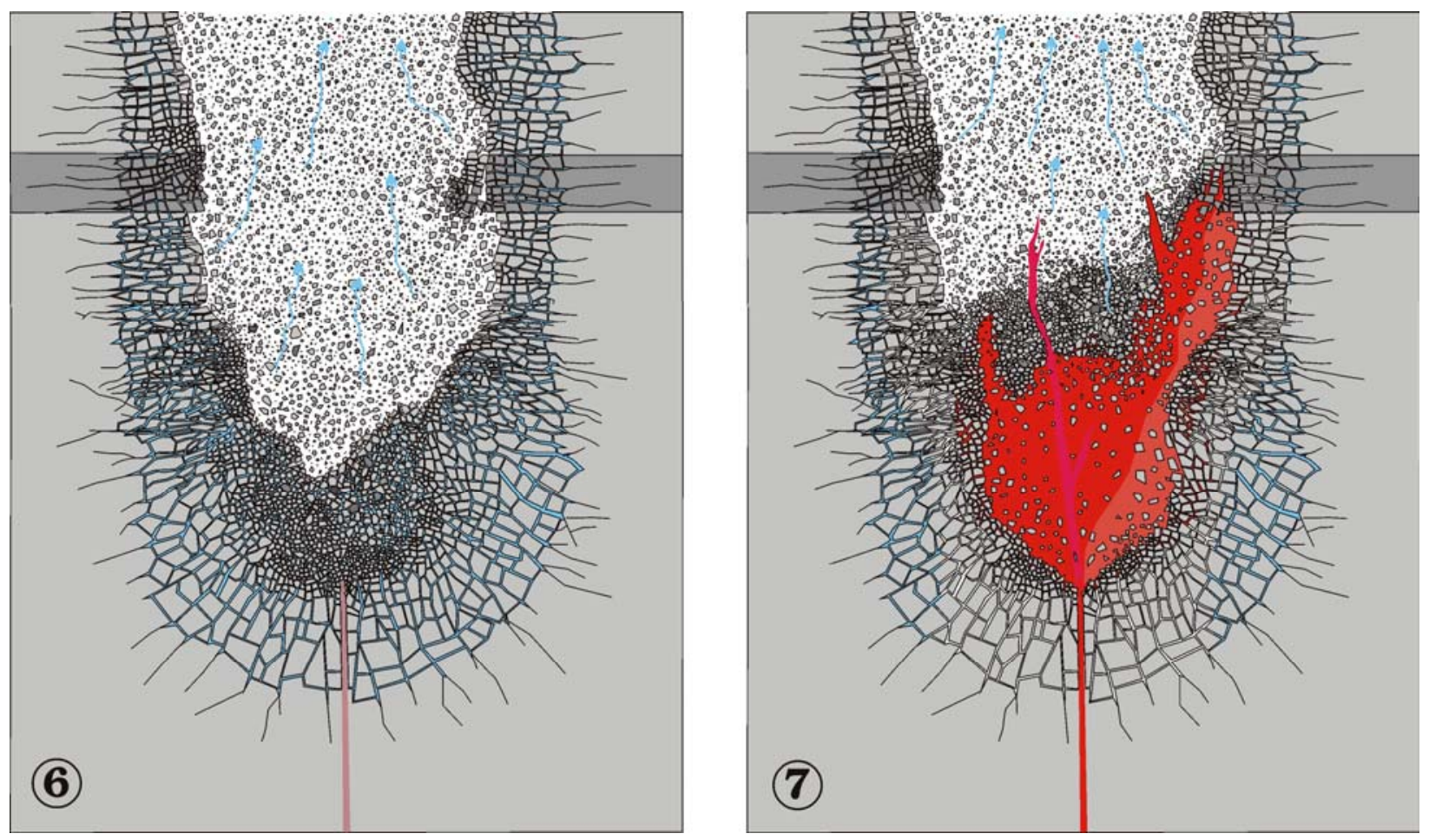

Figure 6: The figure shows one of the possible two extreme end conditions after the volcanic activity ceased. In this case, the magma ascent stopped and water is still entering the root zone and lower diatreme. The root zone consists of a high abundance of country rock and pipe breccias with only little or no intrusive magma present. Groundwater becomes heated and a hydrothermal system is established.

Figure 7: The other extreme shows the condition after the system "ran dry", i.e. the water reflux stopped while magma ascent continued. Magma intrudes the country rock breccia in the root zone and forms plugs and dykes within the root zone and diatreme, whereby dykes can reach high structural zones within the pipe and even reach the surface, where magmatic activity can form a scoria cone, a lava lake, or even a lava flow.

Kurszlaukis, in prep) and the kimberlites in the Shandong and Liaoning Provinces in China (Zhang et al., 1989) may be such cases.

For exploration, the above mentioned constraints imply that if a root zone is discovered in a newly explored area, not all the other undiscovered pipes have to be root zones as well (and vice versa). It also means, that if a root zone is found, exploration activities do not have to be necessarily shifted to "higher ground" to find pipes with rocks of higher structural levels ("crater facies") preserved.

It is, however, important to examine the local hydrogeological situation. One should consider the local stress field at the time of emplacement of the kimberlites to find out the direction of dykes and that of crosscutting faults under dilation. These latter faults may have been hydrologically active and thus the intersection of these faults with dykes are the potential sites of diatreme formation. If in an exploration area only dykes and alluvial diamonds are present then the possibility of an already eroded aquifer should be examined, from which maars or small diatremes (now eroded) could have evolved. This is a possible scenario for the Koidu area in Sierra Leone (Hubbard, 1986) where large alluvial diamond deposits are present but only few root zones and some dykes. There the top of the basement (about 350 to $450 \mathrm{~m}$ below the paleolandsurface) could have represented an aquifer, from which nowadays eroded maars and small diatremes may have evolved.

\section{2: SECONDARY DEPOSITS}

Most of today's kimberlite fields are considerably eroded, preserving often only the lower portions of kimberlite pipes. All higher structural levels of pipes (which are usually volumetrically more important regarding their ore reserves) within those fields are eroded, which thus also includes smaller pipes, shallow root zones and all forms of volcanic surface expressions the kimberlites may have had: scoria cones, lava flows, proximal and distal tephra, etc. If an area has a high concentration of alluvial diamonds and only few, often deeply eroded pipes related to it, then the original 
volcanic field which produced the alluvial diamonds may have had many more volcanoes at higher, nowadays eroded structural levels.

In addition, an estimation of the abundance of diamonds eroded from a single pipe can be made: assuming that the xenolith/tephra ratio is roughly constant throughout the pipe and the erosion rate and diamond grade is known, the volume of the eroded pipe portion (projected) plus that of the ejected tephra (constrained over the country rock content in the pipe) multiplied by the diamond grade results in a rough estimation of diamonds eroded from a pipe.

Since maar-diatremes are usually fed by dykes and since maar-ejecta and diatreme-fills consist of a mixture of juvenile material $(\mathbf{V j})$ and accessory clasts $(\mathbf{V p})$ it is possible to roughly estimate the total volume of clastic material $\mathbf{V p}+\mathbf{V j}$ involved. For model calculations if the proportion of juvenile pyroclastic material $\mathbf{V j}$ in a kimberlite pipe and in the originally associated maar ejecta is taken as $40 \%$ then the total amount of fragmented country rocks would be $60 \%$. The country rock material $(\mathbf{V p})$ originally occupying in an unfragmented state the volume of the diatreme and maar crater is:

$$
\mathrm{Vp}=1 / 3 \pi \cdot \mathbf{r}^{2} \cdot \mathbf{h}
$$

with $r$ being the radius of the top diameter of the pipe, (assuming a circular top end), and $h$ being the depth of a regular cone shaped pipe (the root zone and magmatic kimberlite intrusions are omitted). If $40 \%$ juvenile material is added during explosions and eruptions to result in a 40:60 \% ratio of juvenile to xenolithic material then the total amount of juvenile kimberlite material would be:

$$
V j=\left(1 / 3 \pi \cdot r^{2} \cdot h\right) \cdot 0.4
$$

After formation of a kimberlite pipe, its crater, and its maar ejecta, this juvenile kimberlite material would in part occur inside the kimberlite pipe as well as in the kimberlite maar ejecta. The exact volume respectively mass relationships between the diatreme, maar crater, and maar ejecta as well as between country rock and juvenile material are given by Lorenz (1973) and Mertes (1983). If the average carats of diamonds per ton of juvenile material of a kimberlite maar-diatreme volcano would have been distributed regularly throughout the original volcano then the total carats involved could be calculated. The problem with many kimberlite pipes is, however, that their maar ejecta are eroded and that often even the crater level and upper levels of the diatreme are eroded too. As a consequence of the erosion most of the original volume of the clastic material (fragmented country rocks and juvenile material) has been eroded already and also most of the diamonds have been eroded and deposited elsewhere. Future exploration for alluvial diamonds from eroded kimberlite maar-diatreme deposits has to take into account the percentage of juvenile material in the diamond-rich and diamond-poor pipes of a volcanic field, the average carats per ton of juvenile material in these pipes, the erosion of the kimberlite maar ejecta shortly after the eruptions, the later erosion of upper diatreme levels during periods of regional uplift, the paleodrainage systems through time, and the associated sediment basins related to them.

\section{REFERENCES}

Dawson, J.B., 1994. Quaternary kimberlitic volcanism on the Tanzanian Craton. Contrib. Mineral. Petrol. 116, 473485.

De Maiffe, D., Fieremans, M. and Fieremans, C., 1986. The kimberlites of Central Africa: A review.- Paper presented at the International Congress on magmatism of Extensional Regions Lubumbashi, Zaire, pp. 10-15.

Hubbard, F.H., 1986. The diamond-source kimberlite paradox of Sierra Leone: an alternative kimberlite emplacement model. J. Afr. Earth Sci. 5-6, 599-605.

Kurszlaukis, S. and Barnett, W.P., 2003. Volcanological and structural aspects of the Venetia Kimberlite Cluster a case study of South African kimberlite maardiatreme volcanoes. South African Journal of Geology, in press (see also this volume).

Lorenz, V., 1973. On the formation of maars. Bull.Volcanol. 37-2, 1-22.

Lorenz, V., 1985. Maars and diatremes of phreatomagmatic origin: a review. Trans. Geol. Soc. S. Afr. 88, 459470.

Lorenz, V., Kurszlaukis, S. 2003. Root zone processes and diatreme growth in kimberlite and other maardiatreme volcanoes. In prep.

Mahotkin, I., Robey, J., Kurszlaukis, S., Valuev, E., Pylaev, N., 2003. Pipe emplacement model of the Lomonosov diamond deposit, Arkhangelsk region, NW Russia. $8^{\text {th }}$ International Kimberlite Conference, Victoria, Canada, extended abstract (this volume).

Mertes, H., 1983. Aufbau und Genese des Westeifeler Vulkanfeldes. Bochumer geol. u. geotechn. Arb. 9, 1415.

Scott Smith, B.H., Orr, R.G., Robertshaw, P., Avery, R.W., 1998. Geology of the Fort a la Corne kimberlites, Saskatchewan. $\quad 7^{\text {th }} \quad$ International Kimberlite Conference, Cape Town, South Africa, extended abstracts, pp. 772-774.

Zhang, P., Hu, S., Wan, G. 1989. A review of the geology of some kimberlites in China. Proc. $4^{\text {th }}$ Int. Kimb. Conf. Perth, Australia, pp. 392-400.

Contact: V. Lorenz, Institut für Geologie, Universität

Würzburg, Pleicherwall 1, 97070 Würzburg, Germany.

E-mail: vlorenz@geologie.uni-wuerzburg.de 